\title{
CASES IN NEW CURIA REGIS ROLLS AFFECTING OLD RULES IN ENGLISH LEGAL HISTORY
}

\author{
GEORGE E. WOODBINE
}

In the recently published fourth volume of the Curia Regis Rolls ${ }^{1}$ there occur a number of cases that are worthy of special comment because of their interest and importance to the student of legal history, and because it is not likely that in the coming reviews of the book they will be discussed from the technical point of view of the legal historian.

Chief among these cases is that of Foliot v. Selvein," a writ of right case (begun in the county court and brought into the court of common pleas by a recordari facias) involving a hide ${ }^{3}$ of land in Oxfordshire, in which the tenant had elected to put himself on the grand assise. The twelve knights (mentioned by name in the record) had found that the demandant had greater right to the land than the tenant and judgment had been given accordingly. Thereupon the tenant sued out a writ of attaint against the jurors, and a double jury of twenty-four Inights was selected to attaint the twelve. ${ }^{4}$

This is the only case (in print at least) of attaint brought against a grand assise. Attaint of the jurors of the possessory assises was a very common thing. But in the case of the grand assise it early became the rule that attaint did not lie. ${ }^{\circ}$ The grand assise was established by royal order in 1179. It was

\footnotetext{
1 GuRIa Regis RoLLS OF the ReIgNS of Richard I and JomN (His Miajesty's Stationery Office 1929).

Ibid. 1T, 58-9, 118, 141, 173. Earlier phases of the same case, which had been in the courts a long time, will be found in 3 Curia Regis Rolls 309-10 and 2 Curia Regis Rolls 260, 296.

${ }^{3} \mathrm{~A}$ hide and a half, according to 2 Curia Regis Rolls 260, 296.

4 Because of the failure of some of the jurors to appear the case was adjourned until a later day and nothing more is said about it in this volume. Its conclusion will doubtless be found in succeeding volumes of this same series.

5 Bracton ff. 288b-296; 4 Curia Regis Rolls 81 (cf. 3 Curia Regis Rolls 325-6), 183, 220, 225 (277); 2 Curia Regis Rolls 97-8, 113, 214-15. See Thayer, Prelimmarit Treatise on Evmence (1898) index, sub. tit. attaint.

"In all assises with the exception of the grand assise an attaint usually lies. ... And in a grand assise an attaint does not lie because. ..." Bracton f. 290. "No attaint ever lies after a grand assise." Y. B. 20-21 Edw. I, 19.

` Glanvill, lib. ï. c. 7, 31 ENG. Hrsx. Rev. 268.
} 
consequently less than ten years old when the treatise known as Glanvill was written. Glanvill distinctly says that the ordinance which brought into being the granid assise also provided a penalty when the jurors were attained of perjury. ${ }^{8}$ But no case involving the attaint of a grand assise could be found in the printed material available, though there was plenty of evidence to the effect that the jurors of a grand assise could not be attainted; the passage in Glanvill was explained in various ways to make it fit in with what was undoubtedly the later rule. Foliot $v$. Selvein proves that such explanations are unnecessary, that Glanvill's words meari what they seem on their face to mean - that originally attaint could be brought against the grand assise. But this was not for long. Sometime within the next twenty years the finding of the grand assise came to acquire a finality that could not be brought into question even when the evidence of a false verdict was very apparent.

Two other noteworthy cases are those of Chaplain v. Chevre and Rames $v$. Jolonson. The first of these runs as follows: 10

Ralph Chaplain demands against Hamo Chevre forty eight acres of land with appurtenances in $T$. whereof Michael father of Hamo disseised him without judgment after the first corona-

${ }^{8}$ Poena autem temere iurantium in hac assisa ordinaria ost, ot ipsi regali institutioni eleganter inserta. Si enim iuratores deierasse in curia fuerint legitime convicti vel in iure confessi, catallis et rebus omnibus mobilibus spoliabuntur. Glanvill, lib. ii. c. 19. Beames' translation of Glanvill (as Twiss' translation of Bracton) exroneously translates convioti as "convicted." But convictio, ad convincendum, convicti, etc., aro invariably the technical words used to express attaint, in order to attaint, attainted, etc. In this connection Thayer has made what is, for him, a very unusual mistake. Though he says (op. cit. supra note 5 , at 141), "the attaint (convictio) seems to have originated in England," he also snys (ibid. 140), "In Glanvill there is no mention of the attaint," and he translates the periurasse ... fuerint . . . conviati of his Glanvill text by "convicted of perjury" (ibid. 140, n. 3).

- Prior William v. Thomas de Camville (1227). This is found in Bracton's Note Book, pl. 262. Here a demandant against whom a grand assiso had decided in a writ of right of advowson claimed that the jurors had sworn falsely, and he supported this statement with evidence that seemed so well to substantiate it that the court adjourned the case till a later day in order that it might consult with the king and the justiciar. On the day set for the final hearing the prior did not appear and judgment was given for the tenant. The prior was clearly trying to attaint the grand assise. The tenant seems to have regarded the rule that the grand assise could not be attainted as already so well established that he simply refused to answer the prior's charge of perjury. In the margin of the Note Book some annotator of the text, perhaps Bracton himself, has brought out in a single sentence the point of the case without stating dogmatically the later rule-Nota quod iuratores in magna assisa non poterunt convinci de facili.

10 P. 199, Norf'. 
tion of the king at Canterbury, as it is said, and whereof the assise of novel disseisin was summoned between them before the royal justices at London in the fortnight after Easter; before which term said Michael died. And Robert the attorney of Hamo comes and says that Ralph Chaplain pledged that land to Thomas the son of $H$. B. and that Michael did not disseise him. And Ralph puts himself upon a lawful jury ${ }^{11}$ whether Michael disseised him of his freehold in T., and Robert likewise. Wherefore the sheriff is ordered to cause the assise to come before the justices of the king who are to take assises of novel disseisin etc.

If there has ever been a rule regarded by legal historians as so thoroughly well established that it needed no modification, it was the rule that the assise of novel disseisin would not lie when one of the original parties to the action had died-that is, it would not lie for the disseisee against the heir of the disseisor or for the heir of the disseisee against the disseisor: ${ }^{12}$ Where the original disseisee had been diligent in prosecuting his suit and the action had proceeded to a certain point before the death of either party, a writ of entry sur disseisin would lie.23 The decision in such an action of entry might be made to rest upon a determination of the question of the alleged disseisin if the defendant denied it and put himself upon a jury. But because every jury would by no means be an assisa, (though every assiso, would be a jurata), the records properly call this jury a jurata. and not an assisa.14 This is true even when the jurata is to be composed of members of the original assise (of novel disseisin) which had been summoned but had not functioned because of the death of one of the parties. ${ }^{15}$ Chaplain v. Chevje stands out as a striking exception to this rule of technical nomenclature. The fact that the question to be decided was the one which the original assise of novel disseisin would have had to decide, as also the fact that the court wished to have the determination of it come before justices who had been assigned for the taking of assises (and who could not act beyond the limits of their special commission), may account for this legalis jurata being here called an assisa. . But the real explanation is doubtless to be found in the fact that the rule that a disseisee could not recover in an assise of novel disseisin against the heir of the dis-

\footnotetext{
11 Super legalem juratam. The use of this phrase instead of the more common super juratam or super juratam patriae is very noticeable in the text of this volume. See pp. 22-23, 23-24, 36, 44, 104, 117, 126-27, 129, 134, $136,147,172,199,210,256,256-257,259,271,290-91,307-08,309$.

122 POLLOCK AND IIATTLAND, HISTORY OF TENGLISH LATY (2d ed. 1905) 54-55.

13 Bracton f. 218b; Bracton's Note Book, pl. 76, 131, 372.

24 Bracton's Note Book, pl. 383.

25 Bracton's Note Book, pl. 993.
} 
seisor was very new at this time, and that formerly where the injured party had proceeded against the disseisor so that a view of the land had been made (note that this is the factual requirement for the later writ of entry sur disseisin), the assise would proceed against the heir of the disseisor. That at an earlier time under such circumstances the assise would so proceed is proved by Rames v. Johmson: "ac

The assise comes to recognize if Thomas son of John unjustly and without judgment disseised Master Bennet de Rames of his freehold in T. within the assise. And it is to be known that Thomas died before the assise was to be taken, to wit after' a view of the land had been made. Therefore it is considered that the assise should nevertheless proceed against Eustace brother and heir of Thomas. And the jurors coming say that Thomas so disseised him. Judgment: let Bennet have his seisin.

We shall probably not be wrong in believing that never again in an English court did an assise of novel disseisin proceed as in the case of Rames $v$. Johnson. This case was tried in Trinity term, 1205, just a yean before the case of Chaplain v. Chevre. Within that period, in the fall of 1205 , a writ of entry for the disseisee against the heir of the disseisor was made a writ of course. ${ }^{27}$ This fixed the form of action which a complainant in Bennet de Rames's position must henceforth employ, the form which was employed, under similar circumstances, in Chaplain v. Chevre. But in the latter case, although the action was clearly enough that of the newly made writ of course entry sur disseisin, because the legalis jurato, as far as its functions and their results were concerned was identical with the assisa of only a few months back, the court, unconsciously we may suppose, gave to the new machinery the old name. In other words this court had to forget what we henceforth shall have to remember, that the assise could proceed against the heir of the disseisor.

Attention may be called to another case of novel disseisin 10 because of the light it throws on the question as to the reason for awarding damages in that action. ${ }^{19}$ Here the assise finding for the disseisee, the court awarded him seisin. And damages as follows: "The damage is one cartload of grain and twenty loads of timber and brushwood, three shillingsworth of hog's fat and bacon, and one quarter of flax." While payments in kind of various sorts were common enough in an earlier period

\footnotetext{
16 P. 39, Norf'.

172 PoLIOCK AND MaITLAND, op, cit. supra note 12, at 64 and n. 1.

18 P. 289, Berk'.

10 The matter is discussed in Woodbine, The Origins of the Action of Trespass (1924) 33 YaIE I. J. 799, 807-08. See also Glanvill, lib. xill. c. 38; 1 Curia Regis Rolls 286, 362.
} 
when money was a scarce commodity, as in the time of Henry the First when sheriffs were still settling their accounts at the royal exchequer by this method, for the assessing of damages in the terms here named as late as 1206 there is only one satisfactory explanation. It is an attempt to restore in lind to the disseisee the crops and products taken or consumed by the disseisor. ${ }^{20}$

Fifty years ago Professor Bigelow made the suggestion, since then frequently adopted by others, that the words in the writ of entry ad terminum qui praeteriit had been taken directly from those, in one of the writs in the treatise on debt in Glanvill (lib. x. c. 9), with dimisit substituted for Glanvill's invadiavit.22 In this latest volume of curia regis iolls there are some cases begun by the writ of entry of a type with which Bigelow (presumably because of the scarcity of printed material of this sort at the time he was writing) was apparently not acquainted. In them the original invadiavit of Glanvill's old wit has not been changed to the more familiar dimisit of a slightly later time.2 While these particular cases are new, they do not, as do some of the other cases already mentioned, represent a unique type, as similar cases are to be found in earlier records that have been for some time in print. ${ }^{23}$ They do however round out a mass of evidence ${ }^{24}$ which makes it necessary for us to revise Bigelow's statement, and to say not merely that Glanvill's writ was the exemplar of the later wit of entry ad terminum qui proeteriit, but that it was in fact itself that wit of entry.35

20 Note that there is no mention of a money value in connection with these damages. In this respect the assessment of damages here differs from (though estimated on the same basis as) that in 3 Curia Regis Rolls 287, Herif'.-Dampnum ad valorem sssev. marcarum tam in cstirpations gardini et bosci et domorum et venditione equorum et bovnum et aliortun animalium et ablatione arcarum et vestium suarum et in retardationo seminis sui.

21 Bigelow, History of Procedure in EnjGLAND (1880) 165. See also IIAITLAND, EQUUTY AND THE Formis OE ACTION (1909) 333; Bracton i. 317b-318b; Bracton's Note Book, pl. 183, 188, 313, 425, 499, 575, 650, 663, 751, 761, 787, 790, 964, 1419, 1619, 1868, 1869.

22 There can be do doubt as to their identity; they are in the technical language of typical entry cases. Thus, on p. 204, Ebor', the record reads, Robertus filius Willelmi optulit se izij. die versus WFillelmum do Sonton' de placito duarum bovatarum terre in Santon', in quas non habct ingressum nisi per ipsum Robertum, qui illas ei invadiavit ad terminulm qui preteriit, ut dicitur. See also p. 265, Leicestr. Cf. p. 176, Kent.; p. 210, Lanc'.; p. 268, Mridd'.

${ }^{23}$ With the publication of this fourth volume of curia regis rolls the many thousands of cases recorded on these rolls, through MIichaelmas term, 1206, are all now in print.

24 The earliest case is found on the very first (1194) roll, at the most not more than seven years later than Glanvill. 14 Pipe Roll Society 50.

25 We have been accustomed to regard the writs of entry as coming from 
Glanvill's writ in lib. x. c. 9 is, as the writ of debt ${ }^{20}$ and the later writs of entry, ${ }^{27}$ in the regular praecipe quod reddat form, ${ }^{28}$ the best known example of which in Glanvill's day was the praecipe quod reddat for land in the writ of right group..$^{29}$ In other words, the writ in Glanvill is not necessarily a writ of debt because of its form, that form not being peculiar to debt but common to a variety of writs with very different purposes. ${ }^{30}$ It has heretofore been regarded as a writ of debt, ${ }^{31}$ presumably because it occurs in Glanvill's treatise on that subject, though it is not so called in the treatise itself. The writ of debt, from the time we first see it, was always the same, a writ of right in the praecipe quod reddat form for money or chattels, and for nothing else. Moreover it was a writ for the creditor, not for the debtor. The writ in Glanvill, lib. x. c. 9 is, on the other hand, a praecipe quod 'reddat for land; also it is a writ for the debtor against the creditor. The procedure to which this writ gives rise is not the procedure in an action of debt. The regular method of proof in the latter action was by wager of law. Glanvill seems to intimate, though the cases altogether fail to substantiate his statement, that under certain circumstances there might also be battle in an action of debt; ${ }^{32}$ but there was no place for a jury or the grand assise. Glanvill is very explicit as to the methods of settling the action begun by the writ in lib. x. c. 9. Either the debtor or creditor may ask for a jury trial, and have it; or the case may proceed super recto, that is, it may be decided as an action begun by the writ of right would be decided, by battle or the grand assise. ${ }^{33}$ Now this procedure, though altogether foreign to the action of debt, was the very procedure which had place when an action was begun by a writ of entry. From the time of the first plea rolls on our cases

the period after Glanvill. "Then come the writs of entry invented in the time of Richard, John, and Henry III." "Glanvill gives no writ of entry." IIAITLAND, op. cit. supra note 21 , at 338,339 .

26 Glanvill lib. x. c. 2.

$2 \pi$ For the forms of various writs of entry, neatly tabulated, see MArTLAND, op. cit. supra note 21 , at 379-80.

28 The praecipe quod reddat is analyzed, and compared with the breve do recto tenendo, in ADAMIS, ORIGIN OF THE ENGLISH CoNsTITUTION (1912) 78-82.

${ }^{29}$ See Glanvill, lib. i. c. 6. This is the writ which Glanvill has in mind when he is describing the writ of right procedure. He does not givo an example of breve de recto tenendo till lib. xii. c. 3 .

so The formerly important writ of account was also in this form.

32 Thus BIGELow, op. cit. supra note 21, at 166, says, "it (the writ of entry) is actually nearer to the form of Glanvill's writ of debt, than is the very offspring of that writ, the modern writ of debt."

32 Glanvill, lib. x. c. 5.

${ }^{33}$ Glanvill, lib. x. c. 10. 
show us actions on entry being decided by a jury or super recto, and in no other way..$^{33}$ One other point which associates this writ with the later writs of entry ad terminum qui praeteriit should be kept in mind-like them it is concerned with land the original entry into which had been lawful. So in an action begun by Glanvill's writ we have all the substantial features, factual and procedural, that would be found in an action started by the later writ of entry ad t. q. $p^{35}$ It did just what that writ of entry did and in the same manner. And if we describe the writ of entry, as we rightly may, as a praecipe quod, reddat for land in which the cause of the original lawful entry is stated in the writ, ${ }^{36}$ we have described the writ in Glanvill, lib. x. c. 9.

Probably the chief reason why Glanvill's writ has hitherto failed of recognition as our earliest example of the writ of entry ad t. q. p. is because it does not specifically state the cause of the entry in the words which many generations of students of English law have been taught a writ of entry must have. ${ }^{\text {st }}$ But it was not always necessary that these words should be in a writ of entry, at least in entry ad, t. q. p. They are lacking in Bracton's writ of entry ad. t. q. p..$^{38}$ They were lacking in many similar writs of entry that were issued in the years between Glanvill and Bracton. We can be very certain of this because they do not appear in the words of the records of cases as found in the plea rolls, which records normally preserve the important words of the count, the count and record together reproducing the salient features of the writ and being careful not to be guilty of variations from it. Not that these words are uniformly lacking in the early records. They are found in some cases and are omitted in others, ${ }^{30}$ both types alike being cases of entry

34 Trial by jury-1 Curia Regis Rolls 359-60, 2 Cuxia Regis Rolls 240, 3 Curia Regis Rolls 314; 2 Rotuli Curiae Regis 137, 227. Super recto-1 Rotuli Curiae Regis 410; 1 Curia Regis Rolls 119-20, 188. For a tabulation of the use of battle, grand assise, jury, in the writ of entry cases in Bracton's Note Book see 1 Note Book 181.

35 On matters of procedure in entry see Bracton f. 318-319b.

36 The statement of the cause of the entry was the reason for the great variation in the wording of the writs of entry.

${ }^{37}$ "The tenant it is alleged, had no entry into the land except in a certain mode, which mode will be described in the writ and is one incapable of giving him a good title." 2 POLLOCK AND ITATLAND, op. cit. supra note 12, at 64. The formula in Latin is in quam non habet ingressum jtiri per etc. In Glanvill's writ, though this phrase is lacking, it is perfectly clear, of course, that the entry was made as a result of the land having been pledged.

38 Bracton f. 318. But they are present in other prits of entry which he gives, f. $323-324 \mathrm{~b}$.

$39 \mathrm{~A}$ complete list of all the cases, as far as we have been able to discover them, and in so far as they concern the points under consideration, is here given. There is a case each for the years 1194, 1195, 1196. For 1199 there are nine cases. Of these nine, four have the in quam non habet 
ad. t. $q . p . * 0$

For another thing, Glanvill's writ, unlike the classical writ of entry, has a reference to the sum of money involved. So also do some of the cases of entry found in the early plea rolls. is Apparently the amount of money for which the land had been pledged, clearly immaterial as far as the principle of the action was concerned, ceased to be mentioned because it was unimportant.42 Very evidently the writ of entry ad t. q. p. dia not, as did so many other writs, remain fixed in form from the beginning. ${ }^{43}$ Glanvill's, Bracton's, Fitzherbert's writs of entry ad' t. $q: p$. are all different from one another.

As to the change from invadiavit to dimisit-undoubtedly in Glanvill's time the giving of land as a pledge would be the most usual form of a demise. The word invadiavit (a statement of a fact) was synonymous with the dimisit of a later time. But even after dimisit had become the regular form, invadiavit might still be employed when to use it again stated the fact.4

Less than fifteen years after Glanvill's time we have recorded in a roll the command given to one Roger to restore to another Roger certain land which he had received as a pledge. The sheriff has done just what he is told to do in Glanvill's writ, and for once the one who has been ordered to give back land has done so without more ado. The words used are the words of Glanvill's writ, with the sum not mentioned, but with in

ingressum clause and five lack it. The list follows: 14 Pipe Roll Socioty 50, 135; 24 Pipe Roll Society 235; 1 Rotuli Curiae Regis 341, 361, 410; 2 Rotuli Curiae Regis 37, 38, 85, 137, 211, 227; 3 Historical Collections Staffordshire (Wm. Salt Arch. Soc.) 61; 1 Curia Regis Rolls 102, 119$20,141,167,188,220,247,357-8,359-60,407-08$; 22 Lincoln Record Society no. 438; 2 Curia Regis Rolls 23, 113, 184, 240; 3 Curia Regis Rolls 150-51, 314; Select Civil Pleas (Selden Society). no. 192.

10 Before the twelfth century is out the action of entry ad t. q. p. has so far developed as to produce a writ in the per and cui. (1199) 2 Rotuli Curiae Regis 137. As to the meaning of these terms see MLATLAND, op. cit. supra note 21 , at $379-80$.

\&1 1 Curia Regis Rolls 141 (four marks of silver), 247 (fifteen marks of silver); 2 Curia Regis Rolls 113 (five marks); 2 Rotuli Curiae Rogis 227 (seventeen shillings).

42 In 1200 a demandant told the court that his wife's greatgrandfather had pledged the whole town of Doncaster for five hundred marks of silver, which sum had been repaid. Select Civil Pleas, no. 41.

43 Writs of right and of novel disseisin, for instance, from even as lato a time as the nineteenth century, still follow Glanvill's formulae for those writs word for word.

44 Bracton's Note Book, pl. 171, 234. For the list of cases in the Note Book which use dimisit see note 21 above. Even some of the very early cases, at the time when invadiavit was regularly employed, use commisit. 1 Rotuli Curiae Regis 341, 3 Curia Regis Rolls 150-51. 
quam non habuerunt ingressum nisi per added.t5 The case, which is clearly one of entry ad. t. q. p., has been indexed by the editor of the Select Civil Pleas as ent2y sur plege. So also might the writ in Glanvill rightly be labelled. But by whatever name it is called it must henceforth be recognized as the actual wit of entry ad terminum qui practeriit, and our earliest type of such a writ.

45 Select Civil Pleas, no. 192. 